Journal of Health Promotion and Behaviour (2017), 2(4): 302-312

https://doi.org/10.26911/thejhpb.2016.02.04.02

\title{
Socioeconomic and Cultural Determinants of Early Marriage in Ngawi, East Java: Application of PRECEDE-PROCEED Model
}

\author{
Noviana Ayumi Wijayati'), RB. Soemanto²), Ety Poncorini Pamungkasari3) \\ 1) Masters Program in Public Heath, Universitas Sebelas Maret \\ 2) Faculty of Social and Political Sciences, Universitas Sebelas Maret \\ 3) Department of Public Health, Faculty of Medicine, Universitas Sebelas Maret
}

\begin{abstract}
Background: Indonesia ranks 37 of the countries in the world with the highest rate of early marriage. Center for Gender and Sexuality Studies, University of Indonesia reported in 2015 that Indonesia rank the second highest rate of early marriage in South East Asia. Approximately 2 millions (7.3\%) girls aged under 15 years old have been married and dropped out of school. This number is expected to become 3 million married girls in 2030. This study aimed to determine the effect of socioeconomic and cultural factors on early marriage in Ngawi, East Java.

Subjects and Method: This was an analytical observational study with case control design. Study subjects consisted of 75 women of reproductive age who got married before 20 years old and 75 women of reproductive age who got married had 20-30 years of age. The dependent variable was early marriage. The independent variables were paternal education level, maternal education level, family income, family belief, culture, and peers. The data were collected by a set of questionnaire and analyzed by path analysis model.

Results: Early marriage was positively affected by family belief $(b=1.47 ; 95 \% \mathrm{CI}=0.44$ to 2.50 ; $\mathrm{p}=0.005)$ and culture $(\mathrm{b}=1.56 ; 95 \% \mathrm{CI}=0.54$ to $2.58 ; \mathrm{p}=0.003)$. Early marriage was negatively affected by family income $(\mathrm{b}=-2.20 ; 95 \% \mathrm{CI}=-3.18$ to $-1.21 ; \mathrm{p}<0.001)$ and positive peers $(\mathrm{b}=-2.51$; $95 \% \mathrm{CI}=-3.58$ to $-1.44 ; \mathrm{p}<0.001)$. Family income was affected by paternal education $(\mathrm{b}=2.24 ; 95 \%$ $\mathrm{CI}=0.37$ to $4.12 ; \mathrm{p}=0.019)$ and maternal education $(\mathrm{b}=6.53 ; 95 \% \mathrm{CI}=4.25$ to $8.80 ; \mathrm{p}<0.001)$. Family belief was affected by paternal education $(b=-1.20 ; 95 \% \mathrm{CI}=-2.10$ to $-0.30 ; \mathrm{p}=0.009)$ and maternal education $(b=-1.20 ; 95 \% \mathrm{CI}=-2.10$ to $-0.30 ; \mathrm{p}=0.009)$.
\end{abstract}

Conclusion: Early marriage is directly affected by family income, family belief, culture, and positive peers.

Keyword: early marriage, family education, family income, family belief, culture, peers

\section{Correspondence:}

Noviana Ayumi Wijayati. Masters Program in Public Heath, Sebelas Maret University, Jl. Ir. Sutami 36 A, Surakarta 57126, Central Java. Email: novianaayumi@gmail.com.

Mobile: +6285645828766 .

\section{BACKGROUND}

Marriage is the union of a man and a woman into a happy and everlasting family based on the belief in one and only God. According to the Marriage Act No. 1 of 1974 , article 6 , this covenant of marriage is based on the agreement of both parties of the bride. To marry a person who has not reached the age of 21 (twenty one) year, one must get permission from both parents.
There are various factors that influence early marriage. Having early marriage is just like getting married without readiness and serious consideration. This indicates an unappreciative attitude towards the meaning of marriage as well as undermines the sanctity of marriage (Lubis, 2016). Adolescents who engage in premarital sex have an impact on teenage pregnancies, unplanned pregnancies, 
resulting in abortion and early marriage (Kemenkes, 2015).

Several factors influence the occurrence of early marriage such as knowledge, belief, culture, education, income and peers. These factors correspond to the application of the PRECEDE PROCEED model according to Green Kreuter (2005) in (Sulaeman, 2016). It states that there are three factors can influence behavior, namely predisposing factors (values of beliefs, culture or traditions, knowledge), Enabling factors (education, socioeconomic, infrastructure, age), and Reinforcing factors (factors that reinforce the desired behavior or the influence of significant others in the social environment).

Married at a young age has various effects, especially on women. Young women married at the age of 10-19 years face a nearly five times higher risk of dying in pregnancy and childbirth than women married at the age of 20- 24 years. In addition, early marriage is also linked with a risk of anxiety, depression, experiencing physical, psychological and emotional abuse besides unplanned economic situation that can lead to family quarrels (BPS, 2016). Early marriage can have an impact on health such as HIV and sexually transmitted infections, postpartum hemorrhage, pregnancy anemia, cervical cancer, low birth weight and malnutrition (Ochieng, 2016).

Indonesia ranked 37th among countries with high early marriage (World Fertility Policies, United Station 2011) (Kemenkes, 2015). Data from Center for Gender and Sexuality Studies, University of Indonesia in 2015 states the number of early marriages in Indonesia rank number two in Southeast Asia after Cambodia. There are about 2 millions from $7.3 \%$ under 15 years have married and dropped out of school. This number is expected to increase to 3 millions by 2030 (BKKBN, 2016).

Indonesia's statistics on early marriage is $25 \%$ and some provinces that exceeded that number are East Java with the highest number (39.43\%), Kalimantan (35.48\%), Jambi (30.63\%), West Java (36 $\%$, and Central Java (27.84\%) (UNICEF, 2016). Provinces in Indonesia where there are many women make early marriages are Bangka Belitung 18.2\%, South Kalimantan 17.6\%, East Java 16.7\% (SUSENAS, 2012).

This study attempts to analyze the effect of socioeconomic and determinants of the culture on early marriage.

\section{SUBJECT AND METHOD}

\section{Study design}

This was an analytical observational study with a case control design. The study was conducted in Pitu sub-district, Ngawi regency, East Java.

\section{Population and sample}

In this study the population was all women who did early marriage (age <20 years) in Pitu sub-district, Ngawi Regency. Control population was women who did not do early marriage (age 20-30 years) in Pitu sub- district, Ngawi Regency. Samples were selected by fixed disease sampling.

\section{Study variables}

There were seven variables in this study consisting of dependent and independent variables. The dependent variable was early marriage. The independent variables were paternal education level, maternal education level, family income, family belief, culture, and peers.

\section{Operational definition of variables}

Parental education was defined as the last formal education of parents that obtained a diploma. Family income was defined as an income generated by parents. Family belief was defined as something that is believed to be true. Culture was defined as a habit that 
Journal of Health Promotion and Behaviour (2017), 2(4): 302-312

https://doi.org/10.26911/thejhpb.2016.02.04.02

has been done continuously from the elders or the former people. The role of peers was defined as the role of peers as a source of information, a reference for teenagers. Early marriage was defined as the age at first marriage $<20$ years.

\section{Study instrument}

The data were collected by a set of questionnaire. Data were analyzed using path analysis with Stata. Based on the results of total-item correlation reliability test, it was found that on the measurement of parental belief variables, culture and the role of peers $\mathrm{r}$ calculate $\geq 0.20$, and Cronbach's Alpha $\geq 0.70$, so that all the questions were declared reliable. Reliability test results of the questionnaire can be seen in Table 1.

\section{Data analysis}

Sample characteristics were describe by univariate analysis. Bivariate analysis used Chi square. Multivariate analysis used path analysis to determine the direct and indirect effects of the relationships between study variables. Path analysis steps included model specification, model identification, model fit, parameter estimate, and model respecification.

\section{Research Ethics}

The research ethical clearance was obtained from the Research Ethics Committee at Dr. Moewardi Hospital, Surakarta, Central Java, Indonesia. Research ethics included issues such as informed consent, anonimity, confidentiality, and ethical clearance.

\section{Table 1. Reliability Test Results}

\begin{tabular}{lcc}
\hline \multicolumn{1}{c}{ Variable } & Item Total Correlation (r) & Alpha Cronbach \\
\hline Family belief & $\geq 0.23$ & 0.74 \\
Family culture & $\geq 0.22$ & 0.73 \\
The role of peers & $\geq 0.28$ & 0.72 \\
\hline
\end{tabular}

\section{RESULTS}

The characteristic dimension of 150 subjects was viewed from the age of women at marriage $\geq 20$ years as many as 75 subjects with a percentage of $50 \%$ and $<20$ years as many as 75 subjects with a percentage of $50 \%$. Parental education (father and mother) <senior high school as many as 77 with a percentage of $51.3 \%$ and $\geq$ senior high school as many as 73 with a percentage of $48.7 \%$. Parental income $<\mathrm{Rp}$ $1,444,055$ as many as 74 subjects with a percentage of $49.3 \%$ and $\geq$ Rp1.444.055 as many as 76 subject with a percentage of $50.7 \%$.

Table 2. Characteristics of Study Subjects

\begin{tabular}{|c|c|c|}
\hline Characteristics & $\mathbf{n}$ & $\%$ \\
\hline \multicolumn{3}{|l|}{ Age } \\
\hline$\geq 20$ years & 75 & 50 \\
\hline \multirow{2}{*}{\multicolumn{3}{|c|}{ Paternal Education }} \\
\hline & & \\
\hline$<$ High School & 77 & 51.3 \\
\hline \multirow{2}{*}{\multicolumn{3}{|c|}{ Maternal Education }} \\
\hline & & \\
\hline$<$ High School & 77 & 51.3 \\
\hline$\geq$ High School & 73 & 48.7 \\
\hline \multicolumn{3}{|l|}{ Family Income } \\
\hline$<\operatorname{Rp~1,444,055~}$ & 74 & $49 \cdot 3$ \\
\hline$\geq \operatorname{Rp~1,444,055}$ & 76 & 50.7 \\
\hline
\end{tabular}


Table 3 shows the case group for the paternal education at primary level up to high school with the highest percentage at primary level that is $46.7 \%$. In the control group for the last education at primary level up to college with the highest percentage at high school level is $62.7 \%$. Case group for maternal education at primary to high school level, with highest percentage at primary level that is $46,7 \%$. In the control group for the last education at primary level up to Bachelor Degree, with the highest percentage at high school level is $68 \%$. Case group for family income with highest percentage $<\mathrm{Rp}$ $1,444,055$ is $80 \%$. In the control group for the family income with the highest percentage $\geq \operatorname{Rp} 1,444,055$ is equal to $81.3 \%$. The results of descriptive statistics for continuous data can be seen in Table 4.

Table 3. Characteristics of Subjects with Married Children Age

\begin{tabular}{lcccc}
\hline \multirow{2}{*}{ Characteristics } & \multicolumn{2}{c}{ Ideal Marriage } & \multicolumn{2}{c}{ Early Marriage } \\
\cline { 2 - 5 } Paternal education & $\mathbf{n}$ & $\mathbf{\%}$ & $\mathbf{n}$ & \% \\
Primary & & & & \\
Middle School & 9 & $12 \%$ & 35 & $46.7 \%$ \\
High School & 12 & $16 \%$ & 22 & $29.3 \%$ \\
College & 47 & $62.7 \%$ & 18 & $24 \%$ \\
\hline Maternal education & 7 & $9.3 \%$ & 0 & $0 \%$ \\
Primary & & & & \\
Middle School & 6 & $8 \%$ & 35 & $46.7 \%$ \\
High School & 11 & $14.7 \%$ & 22 & $29.3 \%$ \\
College & 51 & $68 \%$ & 18 & $24 \%$ \\
\hline Family income & 7 & $9.3 \%$ & 0 & $0 \%$ \\
$<$ Rp 1,444,055 & & & & \\
$\geq$ Rp 1,444,055 & 14 & $18.7 \%$ & 60 & $80 \%$ \\
\hline
\end{tabular}

Table 4. Description of the Variables

\begin{tabular}{lccccc}
\hline \multicolumn{1}{c}{ Variable } & $\mathbf{n}$ & Min. & Max. & Mean & SD \\
\hline Married age & 150 & 14 & 30 & 20.61 & 3.39 \\
Family income & 150 & 100, ooo & 4, OoO, o0o & $1,475,333$ & 762,210 \\
Family culture & 150 & 0 & 12 & 3.85 & 1.74 \\
The role of peers & 150 & 1 & 11 & 6 & 2.67 \\
Family belief & 150 & 1 & 10 & 5.38 & 2.31 \\
\hline
\end{tabular}

Table 4 shows descriptive statistics of each variable include minimum value, maximum value, mean value and standard deviation. The table above is for measuring variables with continuous scales, both dependent and independent variables. Mean represents the mean value, whereas the standard deviation (SD) describes how far the data varies. The small SD value is an indication that the data is representative.

The variables of paternal educational level indicated that fathers with education $\geq$ High School had a probability of 0.10 times lower to marry off their children at an early age. It was statistically significant $(\mathrm{OR}=0.10 ; \mathrm{p}<0.001)$. 
Journal of Health Promotion and Behaviour (2017), 2(4): 302-312

https://doi.org/10.26911/thejhpb.2016.02.04.02

The variables of maternal educational level indicated that mothers with education $\geq$ High School had a probability of 0.07 times lower to marry off their children at an early age. It was statistically significant $(\mathrm{OR}=0.07 ; \mathrm{p}<0.001)$.

Family income showed that parents with an income of $\geq \operatorname{Rp~1,444,055~were~}$ likely 0.06 times lower to marry off their children at an early age. It was statistically significant $(\mathrm{OR}=0.06 ; \mathrm{p}<0.001)$.

The culture of early marriage showed that parents with a pro/agree culture in early marriage was 2.67 times more likely to marry off their children at an early age. It was statistically significant $(\mathrm{OR}=2.67 ; \mathrm{p}=$ 0.003).

The role of peer variables suggested that the role of positive peer was likely to be 0.11 times lower for early marriage. It was statistically significant $(\mathrm{OR}=0.11 ; \mathrm{p}<0.001)$.

The parental belief on early marriage variable indicated that parents with belief in consent for early marriage had 5.46 times greater probability of marry off their children at an early age. It was statistically significant $\quad(\mathrm{OR}=5.46 ; \quad \mathrm{p}$ $<0.001)$.

Table 5. Bivariate analysis of family education level, family income, culture, the role of peer, and family belief with early marriage.

\begin{tabular}{|c|c|c|c|c|c|c|c|c|}
\hline \multirow{3}{*}{ Variable } & \multirow{3}{*}{ Category } & \multicolumn{4}{|c|}{ Marriage } & \multirow[b]{2}{*}{ Total } & \multirow{3}{*}{$\mathbf{O R}$} & \multirow{3}{*}{$\mathbf{p}$} \\
\hline & & \multicolumn{2}{|c|}{ Ideal Marriage } & \multicolumn{2}{|c|}{$\begin{array}{c}\text { Early } \\
\text { Marriage }\end{array}$} & & & \\
\hline & & $\mathbf{n}$ & $\%$ & $\mathbf{n}$ & $\%$ & $\%$ & & \\
\hline Paternal & $<$ High school & 19 & 24.7 & 58 & 75.3 & 100 & & \\
\hline Education & $\geq$ High school & 56 & 76.7 & 17 & $23 \cdot 3$ & 100 & 0.10 & $<0.001$ \\
\hline Maternal & & & & & & & & \\
\hline Education & $<$ High school & 17 & 22.1 & 60 & 77.9 & 100 & דרי & $1<001$ \\
\hline $\begin{array}{l}\text { Level } \\
\text { Lacan }\end{array}$ & $\geq$ High school & 58 & 79.5 & 15 & 20.5 & 100 & 0.07 & $<0.001$ \\
\hline Family & $<\operatorname{Rp} 1,444,055$ & 14 & 18.9 & 60 & 81.1 & 100 & 006 & $<0001$ \\
\hline Income & $\geq \operatorname{Rp} 1444,055$ & 61 & 80.3 & 15 & 19.7 & 100 & 0.00 & $<0.001$ \\
\hline Early & Disagree & 45 & 62.5 & 27 & 37.5 & 100 & & \\
\hline Marriage & Agree & 30 & 38.5 & 48 & 61.5 & 100 & 2.67 & 0.003 \\
\hline The Role of & Negative & 25 & 28.7 & 62 & 71.3 & 100 & & \\
\hline Peer & Positive & 50 & 79.4 & 13 & 20.6 & 100 & 0.11 & $<0.001$ \\
\hline Belief in & & & 708 & 21 & ת חפת & & & \\
\hline Early & $\begin{array}{l}\text { Dorsagiee } \\
\text { Agree }\end{array}$ & $3^{+}$ & 70.8 & 21 & 29.2 & 100 & 5.46 & $<0.001$ \\
\hline Marriage & & 24 & 30.8 & 54 & 69.2 & 100 & & \\
\hline
\end{tabular}

Path analysis results showed that early marriage was directly affected by family income, family culture, the role of peer and family belief. Family income $\geq$ Rp $1,444,055$ had a greater possibility of decreasing to marry off their children at an early age $(b=-2.20 ; 95 \% \mathrm{CI}=-3.18$ to -1.21 ; $\mathrm{p}<0.001)$.
Family belief agreed with early marriage were more likely to increase marriage to their children at an early age $(\mathrm{b}=1.47 ; 95 \% \mathrm{CI}=0.44$ to $2.50 ; \mathrm{p}=0.005)$. Family culture agreed on early marriage were more likely to increase marriage to their children at an early age $(\mathrm{b}=1.56$; $\mathrm{CI}$ $95 \%=0.54$ to $2.58 ; \mathrm{p}=0.003$ ). 


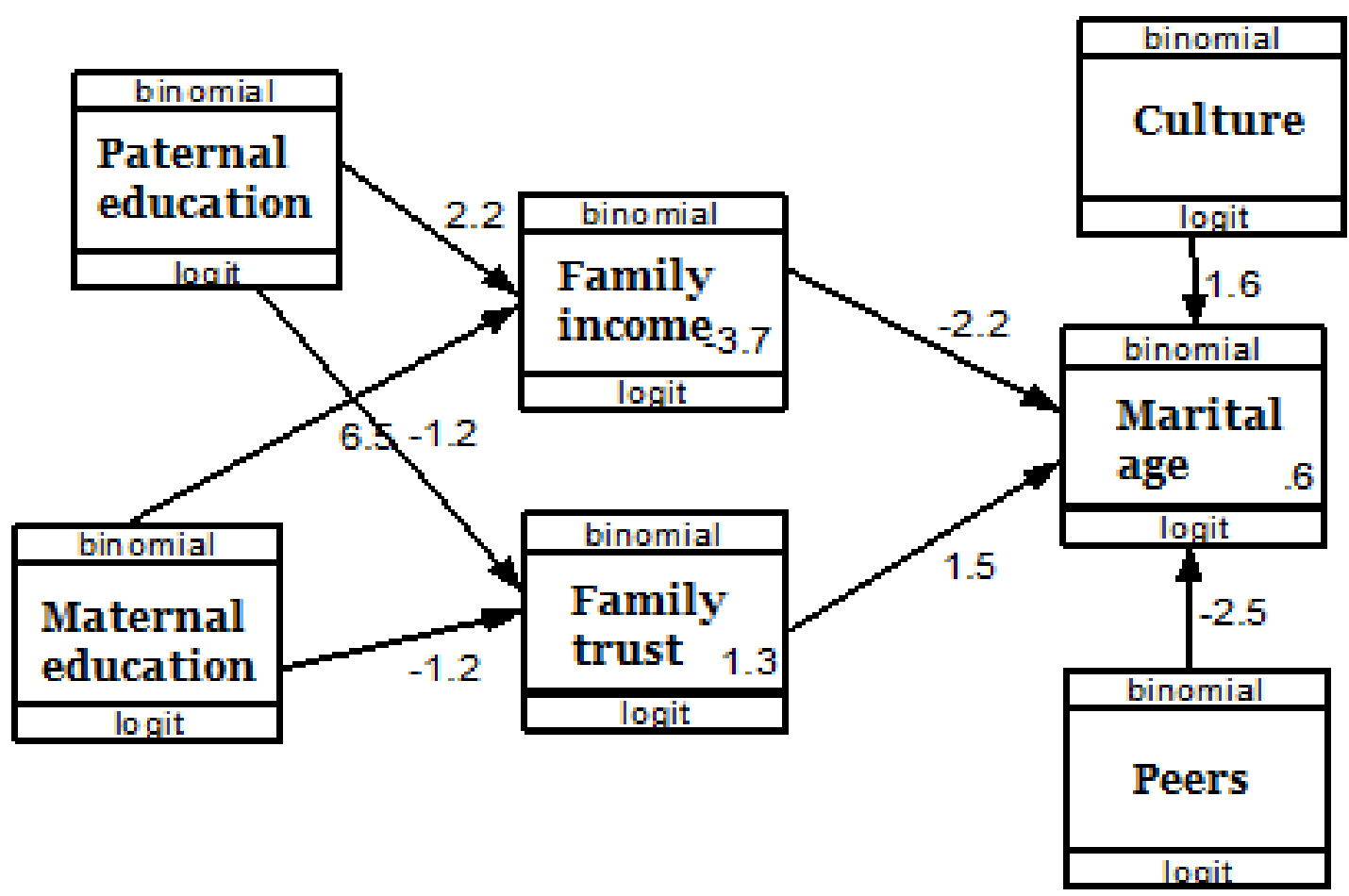

Figure 1. The Structural Model of Path Analysis

Table 6. The Result of Path Analysis

\begin{tabular}{|c|c|c|c|c|c|c|}
\hline \multirow{2}{*}{\multicolumn{2}{|c|}{ Dependent Variable }} & \multirow[b]{2}{*}{ Independent Variable } & \multirow{2}{*}{$\begin{array}{c}\text { Path } \\
\text { Coefficient }\end{array}$} & \multicolumn{2}{|c|}{ CI 95\% } & \multirow[b]{2}{*}{$\mathbf{p}$} \\
\hline & & & & $\begin{array}{l}\text { Lower } \\
\text { Limit }\end{array}$ & $\begin{array}{l}\text { Upper } \\
\text { Limit }\end{array}$ & \\
\hline \multicolumn{7}{|l|}{ Direct Effect } \\
\hline $\begin{array}{l}\text { Early marriage } \\
\text { age }\end{array}$ & $\leftarrow$ & $\begin{array}{l}\text { Family income } \\
\geq \mathrm{Rp} 1,444,055\end{array}$ & -2.20 & -3.18 & -1.21 & $<0.001$ \\
\hline $\begin{array}{l}\text { Early marriage } \\
\text { age }\end{array}$ & $\leftarrow$ & $\begin{array}{l}\text { Family belief } \\
\text { Agree on early marriage }\end{array}$ & 1.47 & 0.44 & 2.50 & 0.005 \\
\hline $\begin{array}{l}\text { Early marriage } \\
\text { age }\end{array}$ & $\leftarrow$ & $\begin{array}{l}\text { Family culture } \\
\text { Agree on early marriage }\end{array}$ & 1.56 & 0.54 & 2.58 & 0.003 \\
\hline $\begin{array}{l}\text { Early marriage } \\
\text { age }\end{array}$ & $\leftarrow$ & The role of positive peer & -2.51 & -3.58 & -1.44 & $<0.001$ \\
\hline $\begin{array}{l}\text { Indirect Effect } \\
\text { Family income } \\
\geq \mathrm{Rp} 1,444,055\end{array}$ & $\leftarrow$ & $\begin{array}{l}\text { Paternal education } \\
\geq \text { High school }\end{array}$ & 2.24 & 0.37 & 4.12 & 0.019 \\
\hline $\begin{array}{l}\text { Family income } \\
\geq \text { Rp } 1,444,055\end{array}$ & $\leftarrow$ & $\begin{array}{l}\text { Maternal education } \\
\geq \text { High school }\end{array}$ & 6.53 & 4.25 & 8.80 & $<0.001$ \\
\hline $\begin{array}{l}\text { Family belief } \\
\text { Agree on early } \\
\text { marriage }\end{array}$ & $\leftarrow$ & $\begin{array}{l}\text { Paternal education } \\
\geq \text { High school }\end{array}$ & -1.20 & -2.10 & -0.30 & 0.009 \\
\hline $\begin{array}{l}\text { Family belief } \\
\text { Agree on early } \\
\text { marriage }\end{array}$ & $\leftarrow$ & $\begin{array}{l}\text { Maternal education } \\
\geq \text { High school }\end{array}$ & -1.20 & -2.10 & -0.30 & 0.009 \\
\hline
\end{tabular}

Positive peer roles were more likely to decrease early marriage $(b=-2.51 ; 95 \% \mathrm{CI}=$
- 3.58 to $-1.44 ; \mathrm{p}<0.001$ ). Family income and family belief were influenced by the 
Journal of Health Promotion and Behaviour (2017), 2(4): 302-312

https://doi.org/10.26911/thejhpb.2016.02.04.02

level of parental education. Paternal education $\geq$ High School had a greater possibility of increasing family income $\geq \mathrm{Rp}$ $1,444,055$ ( $b=2.24 ; 95 \% \mathrm{CI}=0.37$ to 4.12 ; $\mathrm{p}=0.019)$.

Maternal education $\geq$ High School had a greater possibility of increasing family income $\geq \operatorname{Rp~} 1,444,055(b=6.53 ; 95 \% \mathrm{CI}=$ 4.25 to $8.80 ; \mathrm{p}<0.001)$. Paternal and maternal education level $\geq$ High School had a greater possibility of decreasing belief about early marriage $(b=-1.20 ; 95 \% \mathrm{CI}=-$ 2.10 to $-0.30 ; \mathrm{p}=0.009$ ).

\section{DISCUSSION}

\section{Variables that directly affect early marriage}

\section{a. The Role of Peer}

The results showed that the role of peer support directly affected to early marriage and it was statistically significant, both from bivariate, multivariate test and path analysis. It can be said that the influence of friends in making decisions or doing something was very big.

According to the study (Ela et al., 2014), when the environments of many peers have made an early marriage, women also do an early marriage. But, there are differences in the influence of friends between teenagers who get married early and unmarried teenagers. The influence of positive peers makes many teenagers are unmarried because they still want to earn money and make parents happy. The influence of peers is closely related to early marriage. Teenagers who have a negative friend's environment are associated with early marriage (Handayani, 2014).

During adolescents' process of growing up, the influence of parents has shifted to their peers. Teenagers who conducted early marriage are motivated by the influence of groups or peers, as an attempt to become part of a group or peers by following whatever embraced by the group (Salamah, 2016).

It can be concluded from the above description, peer influence is closely related to the occurrence of early marriage. The influence of negative peers would have an opportunity to increase the incidence of early marriage. The influence of positive peers would reduce the incidence of early marriage. Women who spend more time with peers would be easily affected by whatever the peers do either the positive influence or negative influence.

\section{b. Culture}

The result showed that culture directly influenced early marriage and was statistically significant, both from bivariate test, multivariate test and path analysis. The family culture which was pro/agree with early marriage had a greater chance to marry their children off at an early age.

This study is in accordance with research (Bhanji and Punjani, 2014) that parents marry off their children at a young age due to many factors such as coercion of parents, family traditions and the compulsion of relatives. Many parents advised their children, especially women, to get married, because the family assumed that the husbands would take care of their daughters and their children would become more secure.

A study (Fadlyana and Larasaty, 2009) stated that families put pressure on their children to marry as part of family values and traditions. The issue of early marriage was supported by cultures within a community group such as the social stigma of marriage after passing through puberty is considered a disgrace on certain circles, thus increasing the incidence of early marriage.

Early marriage has become customary in the community or considered normal. Many early marriages are conducted with 
processes like matchmaking, age manipulation. Girls' education becomes less considered. Poor parental education also becomes the basis for thinking in making decisions.

From the above description, it can be concluded that parents who still agree with the culture of early marriage will continue to increase the incidence of early marriage. Parents who counter or disagree with early marriage customs could reduce the incidence of early marriage. The occurrence of early marriage is the result of the mindset of every respective parent's.

\section{c. Family Income}

The results showed that family income directly influenced early marriage and was statistically significant, both from bivariate test, multivariate test and path analysis. High family income reduced the incidence of early marriage.

This study is in accordance with research (Djamilah, 2014) that economic factors or poverty was one cause of early marriage. Girls were married off soon to reduce parents' burden. Although there is already a scholarship program or cheap school fees (BOS), but for other costs such as transportation and books became other issues they cannot fulfill it.

Low family income plays an important role in making decisions for early marriage. Early marriage is considered as one of the solutions to get the dowry from the men. Low economic conditions and the assumption that parents are too poor to send their daughters to school, made parents tell their children to marry just to reduce the burden of parents and be independent. Poverty makes it difficult for parents to keep their children at school and parents are attracted by the sweet promises of marriage that will help the family economy (Stang, 2011; Salamah, 2016; Ochieng, 2016).
From the above description it can be concluded that the low family income will increase the incidence of marriage and high family income will reduce the incidence of early marriage. Most of the occurrences of early marriage are caused by family economic factors that become a barrier to send their children to a higher education level.

\section{d. Family Belief}

The results showed that family belief directly influenced early marriage and was statistically significant, both from bivariate test, multivariate test and path analysis. Parents with a pro/agree belief in early marriage were more likely to marry off their children at an early age.

This study is in accordance with research (Mubasyaroh, 2016) in which parents who married off their children at an early age because the adopted religion has no age limit for marriage. The most important aspects for marriage are they have reached puberty and mentally mature. Parents married off their children without thinking about the impact afterwards.

Parents believed by marrying off children will make children more mature. Parents or family still had an important role in making decisions for the children to marry. A daughter in a low-income or poor family is considered an economy burden. Marry off his daughter to an older man is one way to help the family's financial and economy (Montazeri et al., 2016; Bhanji and Punjani, 2014).

From the above description it can be concluded that parents' belief that pro/agree to marry off their children at an early age, can increase the incidence of early marriage. Parents who have started to open mindsets about marriage, like parents who disagree with marry off their children at an early age can reduce the occurrence of early marriage. 
Journal of Health Promotion and Behaviour (2017), 2(4): 302-312

https://doi.org/10.26911/thejhpb.2016.02.04.02

\section{Variables that indirectly affect early marriage.}

a. Effect of parental education level through family income.

The results of the path analysis test showed that the education level had no direct influence with early marriage but through parental income and were statistically significant.

The results of this study indicated that parental education level greatly affected the family income. Parents with low education $<$ high school had a low income and vice versa. This study is in accordance with research (Mubasyaroh, 2016) in which parents who marry off their children at an early age can be the solution to the family's financial problems. Low income makes it impossible for parents to provide their children's needs. Parents marry off their children with a hope of escaping responsibility for financing their needs, so that their children can have a better living.

Many women conduct early marriage because of the low family income, environmental influences and low parental education level. Parents with low level of education and did odd jobs or farming will surely affect the family economy/income (Rafidah et al, 2009)

The study (Sriharyati, 2012) showed that parents who married off their children at an early age were parents who had low education, economically weak and had semi-permanent residence with income that was just only enough for the daily needs of the family.

From the above description, it can be concluded that parental education will affect family income. Parental education $\geq$ senior high school will likely have a higher income. Higher income will make it easier for parents to meet the needs of their children, especially the school needs.

\section{b. Effect of parental education level through parental belief.}

The results of the multivariate analysis and path analysis showed that the education level has no direct influence with early marriage but through parental belief and were statistically significant.

The results of this study indicated that parental education level greatly affected the family belief. Parental education <high school had belief that pro/agree on an early marriage and vice versa. This study is in accordance with research (Redjeki et al., 2016) in which parents who married off their children at an early age had low education level, people's thinking style was very simple. Parents taught that maturity can be seen from marital status.

Parents also still believed that wives should be much younger than their husbands. That belief was one of the factors of early marriage in women. Parents preferred to follow their beliefs by immediately marrying off their children. The study (Bhanji \& Punjani, 2014) stated most of those who embrace that belief were people who lived in rural areas with low education.

Parents marry off their children because of religious factor. According to their belief in the teachings of their religion, there is no marriage age limit. They suggest it is better to avoid pre-marital sex by getting married. Parents also still believe that marrying off their children with relatives or co-workers will build a longlasting relationship between the two. They will also keep the family's good name. The belief is widely embraced by families whose mothers and fathers are not educated. Women just follow what the parents say, because the parents play a role in making decision (Mubasyaroh, 2016; Workineh et al., 2015). 
The conclusion of this study is that parents with education level $\geq$ High School will open their mind concerning the belief that pro or agree about early marriage. Parental belief that agree with early marriage plays an important role in making decision to marry off their children at early age. Parental education is very influential in their beliefs.

\section{REFERENCE}

$\overline{\text { Badan Kependudukan dan Keluarga Beren- }}$ cana Nasional (2016). Mari Bergandengan Tangan Guna Wujudkan Masa Depan Cemerlang Bagi Remaja. BKKBN Jawa Timur.

Bhanji SM, Punjani NS (2014). Determinants of Child (Early) Marriages among Young Girls- A Public Health Issue. Journal of Women's Health Care, 3(3): 1-3. doi: 10.4172/21670420. 1000161.

Djamilah RK (2014). Dampak Perkawinan Anak di Indonesia. Jurnal Studi Pemuda, 3(1): 1-16.

Ela N et al. (2014). Dinamika Perkawinan Dini Pada Remaja Putus Sekolah di Desa Pringkasap Kecamatan Pabuaran Kabupaten Subang Tahun 2014. Universitas Indonesia.

Fadlyana E, Larasaty S (2009). Pernikahan usia dini dan permasalahannya. Sari Pediatri, 11(2): 136-140. doi: 10.14238/sp11.2.2009.136-41.

Handayani EY (2014). Faktor-Faktor Yang Berhubungan Dengan Pernikahan Usia Dini Pada Remaja Putri Di Kecamatan Tambusai Utara Kabupaten Rokan Hulu. Jurnal Maternity and Neonatal, 1(5): 200-206.

Kemenkes (2015). Infodatin Situasi Kesehatan Reproduksi Remaja. Jakarta: Kementrian Kesehatan Republik Indonesia.

Lubis NL (2016). Psikologi Kesehatan Re- produksi Wanita dan Perkembangan Reproduksinya. Jakarta: Perdana Media Group.

Montazeri S et al. (2016). Determinants of Early Marriage from Married Girls' Perspectives in Iranian Setting: A Qualitative Study, Journal of Environmental and Public Health, 1-9. doi: 10.1155/2016/8615929.

Mubasyaroh (2016). Analisis faktor penyebab pernikahan dini dan dampaknya bagi pelakunya. YUDISIA, 7(2): 385411.

Munawara et al. (2015). Budaya Pernikahan Dini Terhadap Kesetaraan Gender Masyarakat Madura. Jurnal Ilmu Sosial dan Ilmu Politik, 4(3): 426-431.

Ochieng B (2016). Determinants of Early Marriage Among Young Women in Homa Bay County In Kenya. University of Nairobi.

Rafidah et al. (2009). Factors Related To Early Marriage At District of Purworejo Centre Java. Berita Kedokteran Masyarakat, 25(2): 51-58.

Redjeki et al. (2016). Faktor-Faktor Penyebab Pernikahan Dini Di Kecamatan Hampang Kabupaten Kota Baru. Dinamika Kesehatan, 7(2): 30-42.

Salamah S (2016). Faktor-faktor yang berhubungan dengan pernikahan usia dini di kecamatan pulokulon kabupaten grobogan. Universitas Negeri Semarang.

Sriharyati T (2012). Faktor-Faktor Penyebab Perkawinan di Bawah Umur di Desa Blandongan Kecamatan Banjarharjo Kabupaten Brebes. Universitas Negeri Yogyakarta.

Stang EM (2011). Faktor Yang Berhubungan Dengan Pernikahan Dini Di Kelurahan Pangli Kecamatan Sesean Kabupaten Toraja Utara. Jurnal MKMI, 7(1): 105-110.

Sulaeman ES (2016). Model dan Teori Peri- 
Journal of Health Promotion and Behaviour (2017), 2(4): 302-312

https://doi.org/10.26911/thejhpb.2016.02.04.02

laku Kesehatan, Konsep dan Aplikasi. Surakarta: UNS Press.

Suryamin (2016). Kemajuan yang Tertunda: Analisis Data Perkawinan Usia Anak di Indonesia. Badan Pusat Statistik Indonesia.

SUSENAS (2012). Policy brief. SUSENAS Republik Indonesia.

UNICEF (2016). Child Marriage In Indo- nesia. BPS Supported UNICEF.

Workineh et al. (2015). Determinants of Early Marriage among Female Children in Sinan District, Northwest Ethiopia. Health Science Journal, 9(6): $1-7$. 